\title{
AN ISOLATE OF BACILLUS SUBTILIS FROM SRI LANKA INHIBITORY TO RHIZOCTONIA SOLANI
}

\author{
R.L.C. WIJESUNDERA
}

Department of Botany, University of Colombo, Colombo 3.

\author{
AND \\ W.H.M.W. HERATH \\ Department of Chemistry, Open University, Nawala, Nugegoda. \\ (Date of receipt : 27 July 1993) \\ (Date of acceptance : 29 December 1993)
}

\begin{abstract}
A deep purple pigmented isolate of Bacillus subtilis obtained from paddy soil inhibited the growth of Rhizoctonia solani, the causative agent of sheath blight of rice. The rod shaped bacterium hydrolysed starch and gelatin, reduced nitrate, was aerobic, formed acetyl methyl-carbinol, catalase positive and spore forming. The inhibitory action was due to the secretion of three inhibitory compounds by the bacterium. The inhibitory compounds are not composed of amino acids and are highly thermostable.
\end{abstract}

Key words: Bacillus subtilis, Rhizoctonia solani, sheath blight inhibitor.

\section{INTRODUCTION}

Rhizoctonia solani Kuhn. causes sheath blight of rice. Sheath blight has become increasingly important in recent years in most rice growing regions of the world including Sri Lanka. The disease at present is mainly controlled by the use of expensive and often harmful fungicides since rice varieties showing high resistance to the fungus has not been developed yet. ${ }^{1}$ Hence, the development of biologically oriented control methods as an alternative to the fungicides becomes increasingly important.

Soil bacteria, especially bacilli, from many localities in different countries have been shown to have inhibitory activity against several plant pathogenic fungi including $R$. solani, and in some instances the active chemical has been identified $\mathrm{d}^{2,3}$; Bacillus subtilis and several other Bacillus species produce polypeptides inhibitory to $R$. solani. ${ }^{2}$ Similar information that would be useful in developing new methods to control plant diseases especially those like the sheath blight of rice, is not available in Sri Lanka.

Here we report the isolation of a soil bacterium, Bacillus subtilis, inhibitory to the rice sheath blight fungus from Sri Lanka, the characteristics of the inhibitory bacterium and preliminary studies on the inhibitory compounds. 


\section{METHODS AND MATERIALS}

The Fungus: The fungus Rhizoctonia solani was isolated from infected plants of rice obtained from the Agriculture Research Station at Bombuwela, Kalutara. Pathogenicity of the fungus was confirmed by following the Koch's postulates. The isolated fungus was maintained on potato dextrose agar (PDA) at $25^{\circ} \mathrm{C}$ during the period of study.

Isolation of Bacteria: Bacteria were isolated from the soil of a paddy field close to Makandura in the North Western Province. From this field (about 0.2 ha in area) six soil samples (each weighing $10 \mathrm{~g}$ ) were collected at random during both the wet and dry seasons. Serial dilutions ( upto $10^{-5}$ ) were made using sterile distilled water. The respective dilutions were plated on peptone sucrose agar (PSA) and nutrient agar (NA) plates and incubated at $30^{\circ} \mathrm{C}$. Pure cultures were obtained from single colonies of the resulting mixed cultures. The pure cultures were maintained on PSA at $30^{\circ} \mathrm{C}$.

Growth of Bacteria for Initial Screening: To initially screen the bacterial isolates for secretion of inhibitory compounds, each isolate was grown in $50 \mathrm{ml}$ of peptone sucrose liquid medium in $150 \mathrm{ml}$ Erlenmyer flasks. Each liquid medium was inoculated with a $1 \mathrm{~cm}$ diameter agar disc obtained from the centre of a 3-day old bacterial culture on PSA. The inoculated media were incubated at $30^{\circ} \mathrm{C}$ and harvested at 1, 3 and $5 \mathrm{~d}$ after inoculation by filtration through a membrane filter $(0.22 \mu$, Millipore). The culture filtrates after concentration (x10) by freeze drying were used to determine inhibitory activity by the filter paper disc method described below. In the control experiments similarly concentrated liquid medium was used instead of the culture filtrate.

Test for Inhibition: The inhibitory tests were carried out on PDA plates at $30^{\circ} \mathrm{C}$. At the periphery of $9.0 \mathrm{~cm}$ diameter petri dishes having the medium, $5 \mathrm{~mm}$ diameter mycelial discs of $R$. solani were kept equidistant to each other and about $3.0 \mathrm{~cm}$ from the centre of the plate. (The mycelial discs were obtained from the periphery of 7 -day old cultures of the fungus on PDA at $30^{\circ} \mathrm{C}$ ). A sterile filter paper disc ( $5 \mathrm{~mm}$ diameter ) dipped in $0.1 \mathrm{ml}$ of the test solution were placed at the centre of the plates containing the mycelial discs. The inoculated plates were incubated at $30^{\circ} \mathrm{C}$ and examined for inhibitory zones. The diameter of any inhibitory zones were measured.

Extraction of the Inhibitor: To obtain the inhibitor in large quantities the bacterial isolate was grown in $500 \mathrm{ml}$ llasks having $200 \mathrm{ml}$ peptone sucrose liquid medium. The liquid medium was inoculated with $2 \mathrm{ml}$ of a 3-day old culture of the bacterium in peptone sucrose liquid medium. The inoculated media were incubated at $30^{\circ} \mathrm{C}$ and harvested 3 days after inoculation by filtration through a bacterial filter $(0.22 \mu$, Millipore ). The resulting filtrate was extracted with methylene dichloride $(200 \mathrm{ml} \times 3)$ followed by ethyl acetate $(200 \mathrm{ml} \times 3)$ based on a method described by Roy et al. ${ }^{4}$. The extracts were evaporated to dryness in a rotary 
evaporator at $30^{\circ} \mathrm{C}$, re-dissolved in $2 \mathrm{ml}$ of the respective solvents and examined for inhibitory activity using the filter paper disc method. In the control equal amounts of the respective solvents were used to treat the filter paper discs.

Chromatography. (Thin Layer Chromatography tlc): Ascending tc using the methylene dicholride extract on silica gel 60 (Merck) glass plates $(20 \times 20 \mathrm{~cm}$ and $0.2 \mathrm{~mm}$ thick) were developed with methylene dichloride : methanol (96:4) for 5-6 h in tanks equiliorated with the solvent system. Inhibitory compounds were detected by the Cladosporium cladosporioides bio-assay ${ }^{5}$ and a modified Cladosporium bio-assay method where instead of the Cladosporium spore suspension a similarly prepared hyphal suspension of $R$. solani were used. To prepare the hyphal suspension a 5-day old culture of $R$. solani on PDA was used. Both the spore and hyphal suspensiors were prepared in a Czapek-dox nutrient medium.

The areas corresponding to the inhibitory zones observed in the bio- assays were eluted 3 times each with $10 \mathrm{ml}$ methylene dichloride, evaporated to dryness at $30^{\circ} \mathrm{C}$ and re-dissolved in $1 \mathrm{ml}$ of the solvent. The inhibitory activity of the re-dissolved extracts were examined by the filter paper disc method. In the control methylene dichloride was used to treat the filter paper discs.

In a seperate experiment, the developed plates were sprayed with $0.2 \mathrm{~g}$ of ninhydrin per $100 \mathrm{ml}$ of $95 \%$ ethanol and heated to $100^{\circ} \mathrm{C}$ for $5-10 \mathrm{~min}$ to detect ninhydrin positive compounds.

Column Chromatography: The dried methylene dichloride extract $(1.2 \mathrm{~g})$ dissolved in $1.0 \mathrm{ml}$ of methylene dichloride was placed on a silica gel (Merck 20g) glass column ( $2.5 \mathrm{~cm}$ diameter). The column was eluted by gravity with a methylene dichloride, methanol mixture of increasing polarity. The flow rate was $2 \mathrm{ml} / \mathrm{min}$ and $8 \mathrm{ml}$ fractions were collected and examined for inhibitory activity by the filter paper disc method.

Characterization of the Bacterial Isolate: Morphological and biochemical characters of the bacterial isolate were examined as described by Kiraly. ${ }^{6}$

Thermal Stability: Equal amounts of the inhibitory compounds eluted from thin layer chromatography as described above were kept at $30^{\circ} \mathrm{C}, 40^{\circ} \mathrm{C}, 50^{\circ} \mathrm{C}, 60^{\circ} \mathrm{C}, 70^{\circ} \mathrm{C}$, $80^{\circ} \mathrm{C}, 90^{\circ}$ and $100^{\circ} \mathrm{C}$ in glass test tubes in a water bath for $30 \mathrm{~min}$. At the end of the time period the tubes were rapidly cooled to room temperature. Afterwards the samples were adjusted to their starting volumes using methylene dichloride and the samples were examined for inhibitory activity. The \% decrease in activity was calculated as follows:

$$
\% \text { decrease }=\frac{X-Y}{X} \times 100
$$


$\mathrm{X}=$ Activity after exposure to $30^{\circ} \mathrm{C}, \mathrm{Y}=$ Activity after exposure to the required temperature. (No decrease in activity is observed after exposure to $30^{\circ} \mathrm{C}$ ).

\section{RESULTS}

Isolation of Bacteria and Initial Screening: A large number of bacteria (95 forms) were isolated from the soil samples. The culture filtrates (harvested at 1,3 and $5 \mathrm{~d}$ ) of all isolates were screened for inhibitory activity. A few isolates ( 12 forms) had a inhibitory effect on the growth of the fungus. The inhibitory effect of only one isolate was persisient - in all other 11 forms the inhibitory effect was temporary (lasting from $12-24 \mathrm{~h}$ ). No inhibitory effects were seen in the control experiment.

In the isolate which showed persistent inhibitory activity, the inhibition was highest in the cuiture filtrate harvested $3 \mathrm{~d}$ after inoculation. This isolate which showed persistent inhibition was chosen for further study. We were unable to isolate the bacterium showing persistent inhibition from soil samples collected during the dry season.

Characters of the Inhibitory Bacterium: The characters observed are listed in Table 1. The colonies on both PSA and NA were small, circular and flat with an entire margin. The colonies had an intense purple colour and the bacterial cells were rod shaped. The bacterium also had the following characters: hydrolysed starch and gelatin, catalase positive, reduced nitrate to nitrite, formed acetyl-methylcarbinol, aerobic and spore forming.

Table 1: Characteristics of the B. subtilis isolate.

Character Description

1. Colonies on NA and PSA

2. Anaerobic growth

3. Catalase

4. Hydrolysis of

Starch

Gelatin

5. Nitrate reduced to nitrite

6. Formation of acetyl methyl carbinol

7. Spore formation
Small, circular and flat.

Deep purple pigment present.

+ Character present, - Character absent.

NA-Nutrient agar, PSA-Peptone sucrose agar. 
When the bacterium was grown in peptone sucrose liquid medium it turned light: purple within $24 \mathrm{~h}$ after inoculation and the colour intensified $48 \mathrm{~h}$ after inoculation. When the liquid ctiture was filtered using a membrane filtre $(0.22 \mu$, Millipore) a clear colourless filtrate free from the pigment was obtained.

Charcterization of the Inhibitor: The methylene dichloride extract of the culture filtrate showed persistant inhibition. Inhibition was totally absent in the ethyl acetate extract. In the control experiments where discs dipped in the respective solvents were used no inhibitory effects were observed.

When the methylene dichloride extract was subjected to the and the Cladosporium bio-assay 3 inhibitory zones were obsereved. The $R_{f}$ values were 0.66 (CI), 0.56 (CII) and 0.31 (CIII). Similar inhibitory zones were also observed in the modified Cladosporium bio-assay. All three zones fluoresced under UV (254 nm) and were ninhydrin negative.

The three zones when examined by the filter paper disc method after elution, inhibited the growth of the fungus. Inhibition was highest in CII followed by $\mathrm{Cl}$ and CIII. The inhibition was persistent. No inhibition was seen in the control experiments.

Column chromatography confirmed the existence of more than one inhibitory compound. Three peaks of inhibition was also obtained when the fractions from the silica gel column were examined for inhibition. Two peaks were in the fractions eluting with methylene dichloride:methanol (98:2) and the other eluting with methylene dichloride:methanol (98:1).

Temperature Stability: The inhibitory compounds showed tolerance to temperatures upto about $60^{\circ} \mathrm{C}$. At this temperature they retained about $85 \%$ of activity. Thereafter, a rapid decline in activity was seen (Table 2).

Table 2: Temperature stability of the inhibitor.

\begin{tabular}{crcr}
\hline & \multicolumn{3}{c}{$\%$ Decrease in Activity } \\
Temperature $\left({ }^{\circ} \mathrm{C}\right)$ & C I & CII & C III \\
\hline 40 & 3.0 & 2.5 & 2.2 \\
50 & 5.0 & 6.0 & 4.5 \\
60 & 14.0 & 10.0 & 11.0 \\
70 & 59.0 & 65.0 & 70.0 \\
80 & 81.0 & 78.0 & 100.0 \\
90 & 100.0 & 100.0 & - \\
\hline
\end{tabular}

\footnotetext{
- Activity at $30^{\circ} \mathrm{C}$ was taken as $100 \%$

Mean of 3 replicates.
} 


\section{DISCUSSION}

The morphological characters observed indicate that the inhibitory bacterium is a Bacillus species. The ability to hydrolyse starch and gelatin, formation of acetyl methyl-carbinol and reduction of nitrate strongly suggest that the bacterium is an isolate of Bacillus subtilis. ${ }^{7}$ The characteristic deep purple colour was due to an intra-cellular pigment. The colour was always absent in the cell free culture filtrates.

The characters of $B$. subtilis isolates as given in the Bergeys' manual ${ }^{8}$ show that the formation of pigments is not a common occurrence. Brown, red, orange and black are the pigment colours reported. It does not mention a deep purple pigmentation. Hence, the present isolate has a very characteristic pigment.

The inhibitory action was due to 3 compounds secreted by the bacterium. The ninhydrin test indicates that the 3 compounds do not have any amino acid or protein residues. The inhibitory compounds of $B$. subtilis reported by Loeffler et al. ${ }^{2}$ are all different forms of peptides. Therefore, the inhibitory compounds of this isolate of B. subtilis are different from those reported.

The activity of the inhibitory compounds detected were persistent and they show a high degree of temperature tolerance - they retain most of their activity even after, exposure to $60^{\circ} \mathrm{C}$. They are, therefore, well suited to Sri Lankan environmental conditions. Hence, the bacterium or the individual compounds have the potential to be developed as useful bio-control agents against the sheath blight fungus.

\section{Acknowledgement}

The financial assistance from NARESA (Research Grant RG/88/B/05) for this project is acknowledged. The Department of Biological Sciences, University of Illinois at Chicago, U.S,A. is thanked for providing facilities for identifying the bacterium.

\section{References}

1. Wickremasingha D.L. \& Mithrasena Y.J.P.K. (1989). Sheath blight disease of rice in the low country wet zone of Sri Lanka; Effect on yield and factors influencing spread and distribution. Tropical Agriculture Research Series 22: 38-48.

2. Loeffler W., Tschen J.S.M., Vanittanakom N., Kugler M., Knorpp P., Hsiech T.G. \& Wu T.G. (1986). Anti-fungal effects of Bacilysin and Fengymycin from Bacillus subtilis F-29-3. A comparison with other Bacillus antibiotics. Journal of Phytopathology 115: 204-213. 
3. Mckeen C.D., Rielley C.C. \& Pusey L.L. (1986). Production and partial characterization of antifungal substances antagonistic to Monilinia fructigena from Bacillus subtilis. Phytopathology 76: 136-139.

4. Roy K., Mukhopadhyay T., Reddy G.C.S., Desikan K.R., Rupp R.H. \& Ganguli B.N. (1988). Aranorosin, a novel antibiotic from Pseudoarachniotus roseus. Joumal of Antibiotics 41: 1780-1784.

5. Smith D.A. (1982). Toxicity of Phytoalexins. In Phytoalexins (Eds. J.A. Bailey \& J.W. Mansfield). pp. 218-252. Blackie, London.

6. Kiraly Z., Klement Z., Solymosy F. \& Voros J. (1974). Methods in Plant Paihology pp. 215-225. Elsevier Scientific Publishing Co., London.

7. Burrows W. (1973). Text Book of Microbiology. pp.607-615. Saunders, Philadelphia.

8. Bergeys' Manual of Systematic Bacteriology. Vol 2. (1986). List of species of the genus Bacillus. pp. 1127-1130. Williams and Wilkins, Baltimore. 